Jakub Pieczara

Uniwersytet Pedagogiczny im. Komisji Edukacji Narodowej

w Krakowie

\title{
Sławomir Filipek, Obraz Matki Bożej Śnieżnej w Tokarni: studium nad ikonografia ,'Salus Populi Romani", Wydawnictwo Muzeum Archidiecezjalne Kardynała Karola Wojtyły w Krakowie, Kraków 2017, sS. 135
}

Książka ks. Sławomira Filipka już od pierwszych stron jawi się jako bardzo przemyślana monografia. Niewątpliwie na rzetelne podejście do tematu wpłynęły względy osobiste. Autor wskazuje we wstępie na niezwykłe przywiązanie do swojej rodzinnej parafii w Tokarni. Szacunek, jakim darzy swoją małą ojczyznę, a w szczególności znany od dzieciństwa wizerunek Matki Boskiej Śnieżnej, wywiera na czytelniku ogromne wrażenie. W monografii ks. Filipek, poza głównym jej celem, jakim było opisanie historii obrazu, wskazanie genezy i symboliki przedstawienia wizerunku Matki Boskiej, pokusił się również o teologiczną interpretację macierzyńskiej relacji i miłości Maryi do Jezusa.

Recenzowana praca została podzielona na wstęp, trzy rozdziały z podrozdziałami, zakończenie, bibliografię oraz wykaz skrótów. We wstępie autor po wskazaniu celów badawczych przedstawił opracowania, w których znajdują się ogólne informacje o tytułowej wsi. Na uwagę zasługuje liczba wymienionych opracowań i publikacji, w których można znaleźć szczątkowe informacje o Tokarni. Autor podkreśla, że żadne dotychczasowe opracowanie nie zawiera głębszej analizy tokarskiego obrazu. Ponadto wskazuje archiwa zawierające główne źródła wykorzystane w pracy: Archiwum Parafialne, Archiwum Kurii Metropolitalnej w Krakowie oraz Archiwum Wojewódzkiego 
Konserwatora Zabytków w Krakowie. Wśród źródeł uwagę zwraca szczególnie kronika ks. Antoniego Gagatnickiego, który był profesorem Seminarium Duchownego w Przemyślu, a jednocześnie krewnym właścicieli dworu i dóbr ziemiańskich w Tokarni. Można domniemywać, że informacje w niej zawarte mogą być przydatne zarówno dla historyków zajmujących się lokalną czy regionalną historią wsi w Małopolsce, jak i historyków sztuki badających historie dworów w Galicji. Głównym problemem, z jakim ks. Filipek spotkał się podczas kwerendy, był skąpy materiał źródłowy, co wynikało z administracyjnej przynależności kościoła w Tokarni do parafii w Łętowni aż do roku 1982. Reasumując, we wstępie ks. Filipek wskazuje podstawę źródłową, która była wynikiem solidnie przeprowadzonej kwerendy archiwalnej.

W pierwszym rozdziale pt. Zarys parafii pod wezwaniem Matki Boskiej Śnieżnej w Tokarni autor przybliża czytelnikowi historię Tokarni oraz samej parafii. W sposób typowy dla historycznych monografii wieś w pierwszej kolejności została scharakteryzowana ze względu na położenie geograficzne, a kolejno ze względu na niejednoznaczną genezę nazwy miejscowości, historyczne wzmianki w źródłach oraz układ przestrzenny. Następnie ks. Filipek przybliżył postacie właścicieli Tokarni, przedstawiając najważniejsze informacje dotyczące poszczególnych osób. Opisując historię parafii i kościoła, autor przedstawia historyczne wzmianki oraz zachowane teksty dotyczące pierwszych miejsc religijnych na opisywanym terenie. Rozpoczyna od kaplicy dworskiej ufundowanej przez właściciela Tokarni, Spytka Wawrzyńca Jordana lub jego małżonkę Annę w roku 1570. Znajdowały się w niej dwa ołtarze, a na nich obrazy, z których jeden - Ukrzyżowanie - zachował się do dnia dzisiejszego. Tytułowa Matka Boska Śnieżna zastąpiła drugi obraz około 1680 roku. Z biegiem lat świątynia była poddawana kolejnym renowacjom, remontom i modernizacjom, co jest skrupulatnie opisane. Na początku XXI wieku wybudowano nowy kościół, a stary został w całości przeniesiony do skansenu w Zubrzycy Górnej, oddalonej o około 35 km od Tokarni.

Drugi rozdział, zatytułowany Obraz Matki Boskiej Śnieżnej w kontekście kulturowo-historycznym, rozpoczyna przedstawienie historii rzymskiej bazyliki Santa Maria Maggiore (uprzednio pod wezwaniem Matki Boskiej Śnieżnej), z którą bezpośrednio związana jest legenda mówiąca o śniegu stanowiącym znak miejsca wybranego przez Maryję na budowę świątyni na wzgórzu Eskwilin. Następnie autor przybliża historię ikony Salus Populi Romani, opinie historyków o dacie jej powstania, a także sygnalizuje istnienie legend i opowiadań związanych z dziełem. Odpowiednio posługuje się metodologią i szczegółowo charakteryzuje ikonę. W dalszej części 
rozdziału omawia rozwój kultu maryjnego, opisując najważniejsze dogmaty, które doprowadziły do rozpowszechnienia kultu Świętej Bożej Rodzicielki. Ksiądz Filipek wyszczególnia miejsca kultu maryjnego w Europie i w Polsce od średniowiecza do XVI wieku włącznie, kończąc wspomnieniem Soboru Watykańskiego II, Pawła VI oraz Jana Pawła II. Ostatni podrozdział w tym rozdziale został poświęcony ikonografii Matki Boskiej Śnieżnej. Autor wymienia najstarsze i najważniejsze obrazy ilustrujące opad śniegu, który zgodnie z legendą wskazywał miejsce budowy nowej świątyni podczas pontyfikatu papieża Liberiusza. Są to między innymi dzieła Filippa Rusutiego, Masolina de Panicale, Niccolò Soggiego czy Bartolomea Estebana Murilla.

Rozdział trzeci, zatytułowany Tokarski obraz Matki Boskiej Śnieżnej a inne przedstawienia tego typu, rozpoczyna się przedstawieniem historii obrazu. Autor na początku zaznacza, że nie udało mu się dotrzeć do nowych faktów historycznych, które mogłyby zmienić postrzeganie historii obrazu Matki Boskiej Śnieżnej znajdującego się w kościele parafialnym. Należy stwierdzić, że obraz znajdował się na terenie obecnej parafii już XVII wieku. Ważną datą związaną z historią obrazu i świątyni jest rok 1846, kiedy kościół w Tokarni otrzymał przywilej odpustu w Uroczystość Matki Boskiej Śnieżnej. Następnie autor opisuje kwestię renowacji oraz bardzo ważną dla wszystkich parafian chwilę koronacji obrazu, która nastąpiła 1 października 2016 roku. Znaczną część rozdziału poświęca oczywiście dokładnej charakterystyce i analizie obrazu. Wyraźnie widać w tym miejscu dobry warsztat metodologiczny, który autor mógł szlifować na Wydziale Historii Sztuki Uniwersytetu Papieskiego Jana Pawła II w Krakowie. Należy również podkreślić, że materiał ikonograficzny, który w znacznym stopniu uzupełnia treść opracowania w tej części, robi największe wrażenie. Autor przedstawia zdjęcia ikony podczas konserwacji w promieniach UV, IR oraz bez dodatkowego światła, ostatecznie prezentując dzieło po konserwacji. Podsumowując przeprowadzoną analizę ikony, podkreśla on rzadkość pojawiania się na jednym obrazie zarówno Matki Boskiej, jak i symbolu Ducha Świętego. Ostatni podrozdział zawiera analizę porównawczą obrazu w Tokarni z innymi dziełami Matki Boskiej Śnieżnej. Ksiądz Filipek przedstawia wyraźny podział na grupy, do których można przyporządkować tematyczne obrazy. Wskazuje najstarsze kopie ikony Salus Populi Romani, które zostały przywiezione na tereny Rzeczypospolitej. Jedna znajduje się w bocznej kaplicy oo. Dominikanów w Krakowie. Kolejny obraz mieści się w kościele św. Tomasza u sióstr duchaczek. Następne dwie kopie przywiezione zostały do Polski przez dominikanów, jedna do Lublina, a druga do Podkamienia na Wołyniu. Powyższe przykłady należą do pierwszej grupy kopii 
rzymskiej ikony, które zostały przywiezione do Polski. W zaproponowanym podziale autor nie kierował się miejscem powstania, lecz formą przedstawienia Matki Boskiej. Dlatego do tej samej grupy należy także obraz znajdujący się w Tokarni. Dodatkowo ks. Filipek wymienia inne obrazy Matki Boskiej Śnieżnej - znajdujące się w Racławicach Olkuskich, Andrychowie, Makowie Podhalańskim czy Zielenicach koło Krakowa. Druga grupa to odwzorowania polskich przedstawień Maryi. Należą do niej: obraz znajdujący się w kościele parafialnym pw. Narodzenia Najświętszej Maryi Panny w Ostrowąsie w diecezji wrocławskiej, obrazy w Świętej Lipce, Czerwińsku czy Berdyczowie. Trzecią grupę ikon stanowią ukazania całopostaciowej Matki Boskiej, jak w przypadku obrazów znajdujących się w Krakowie (przy ulicy Mikołajskiej, na Gródku w kościele sióstr Dominikanek), sanktuarium w Stoczku Warmińskim czy Lewiczynie. Ostatnia, czwarta grupa, zawiera obrazy, które były wzorowane na rzymskiej ikonie Salus Populi Romani, jednak wykonane zostały przez malarzy i rzeźbiarzy ludowych. Przykładami w tej grupie są: Matka Boska Śnieżna w kościele parafialnym w Wysokiej obok Jordanowa, w Pieraniach koło Inowrocławia czy we wsi Jodłówka w powiecie Jarosławskim na Podkarpaciu.

Należy pamiętać, że autor wybrał subiektywnie kilka reprezentacyjnych przykładów obrazów o tej samej tematyce, znajdujących się w różnych stronach naszego kraju. Bardzo dobrze wpisały się w koncepcję ukazania obrazu Matki Boskiej Śnieżnej w Tokarni, na tle innych dzieł. Podsumowując, autor przedstawia najbardziej rozpowszechnione wizerunki Maryi z Dzieciątkiem na terenie Rzeczypospolitej. Najczęściej spotykanym wizerunkiem jest Matka Boża Piekarska, później Matka Boża Częstochowska, a trzecie miejsce zajmuje opisywana Matka Boska Śnieżna.

Tytuł książki w pełni oddaje treść pracy. Pozycja jest solidnym studium przypadku obrazu w typie Matki Bożej Śnieżnej znajdującego się w Tokarni. Praca jest opatrzona bibliografią, w której autor dokonuje podziału na źródła, dokumenty kościelne, literaturę przedmiotu oraz literaturę pomocniczą, dodając wykaz skrótów. Największym mankamentem książki jest wynikający z przyjętej koncepcji pracy brak netografii (źródeł internetowych), na której w znacznej mierze opiera się materiał fotograficzny. Uważam jednak, że pomimo tego praca zasługuje w pełni na uznanie. Należy docenić fakt podjęcia tematu, z którym autor jest emocjonalnie związany. W przyszłości książka z pewnością posłuży historykom sztuki badającym obrazy Matki Bożej Śnieżnej na terenie naszego kraju. Na szczególną uwagę zasługuje bogaty materiał ikonograficzny (43 ilustracje) uzupełniający treść publikacji. Przygotowana przez ks. Sławomira Filipka praca może być znakomitym wzorem dla podobnych opracowań. 